\title{
Chinua Achebe's postcolony: a literary anthropology of postcolonial decadence
}

\author{
Rogers Orock
}

Anthropology Department, University of the Witwatersrand, Johannesburg, South Africa and Department of Sociology and Anthropology, University of Buea, Buea, Cameroon

Email: rogers.orock@wits.ac.za

\begin{abstract}
Can the African novel work as interlocutor for anthropologists studying Africa's postcolonial politics today? Conversely, is there a role for the African literary imagination in our renewed efforts to decolonize anthropology? This article draws on Chinua Achebe's fictional representations of the postcolony in two novels, No Longer at Ease and A Man of the People, to discuss the value of the African literary archive for an anthropological interest in elites, corruption and postcolonial decadence in the early postcolony. This African literary archive has contributed enormously to Achille Mbembe's critique of power in the postcolony. Here, I argue that, in contrast to anthropologists of the late colonial and early postcolonial moment, African writers such as Achebe mobilized fiction as a powerful form of critique to address early signs of postcolonial despair and disillusionment in Africa.
\end{abstract}

\section{Résumé}

Le roman africain peut-il servir d'interlocuteur pour les anthropologues qui étudient aujourd'hui la politique postcoloniale en Afrique ? Inversement, l'imaginaire littéraire africain a-t-il un rôle à jouer dans nos efforts renouvelés de décoloniser l'anthropologie ? Cet article s'appuie sur les représentations fictionnelles de la postcolonie de Chinua Achebe dans deux de ses romans, No Longer at Ease et A Man of the People, pour débattre de la valeur des archives littéraires africaines pour un intérêt anthropologique pour les élites, la corruption et la décadence postcoloniale en début de la postcolonie. Ces archives littéraires africaines ont énormément contribué à la critique du pouvoir en postcolonie d'Achille Mbembe. L'auteur soutient que, contrairement aux anthropologues de la fin de la période coloniale et du début de la période postcoloniale, les écrivains africains comme Achebe ont mobilisé la fiction en tant que forme puissante de critique pour traiter des premiers signes de désespoir et de désillusion postcoloniaux en Afrique.

\section{Introduction}

'The African is corrupt through and through. They are all corrupt.' So accustomed are we to racist stereotypes of Africa and Africans, there is almost nothing shocking about unrestricted re-use, distribution, and reproduction in any medium, provided the original work is properly cited. 
this statement. ${ }^{1}$ Yet, one may misrecognize its provenance. Formulated in these exact terms, the statement is made in the context of Nigeria at the dawn of independence. It is spoken by Mr Green, Obi Okonkwo's boss in Chinua Achebe's second novel, No Longer at Ease (1960). Green makes this racist remark after playing tennis 'with a friend who worked for the British Council' in the company of 'many other Europeans' in a bar that was formerly exclusive to Europeans and remains 'technically' so (ibid.: 3). Almost offhandedly, it is Mr Green's British Council friend who prompts this remark when he claims that he 'cannot understand why' Obi Okonkwo would agree to 'take a bribe' given his status as 'a young man of great promise' who has a respectable 'education' from the UK at a time when few are so privileged (ibid.: 2). Mr Green's damning response poses the question: how should we understand the regimes of corruption that were emerging in nascent postcolonial states in Africa and the role of the new African elites within these regimes of corruption?

According to Bill Ashcroft and colleagues (1995: 2), one of the main challenges confronting postcolonial societies has been 'the development of the new elites within independent societies'. This article examines elites and corruption in what I call, following Achille Mbembe, the early postcolony in Africa. 'The postcolony,' Mbembe writes, 'identifies specifically a given historical trajectory - that of societies recently emerging from the experience of colonisation and the violence which the colonial relationship, par excellence, involves' (1992: 3; see also 2001: 201). As an anthropologist studying and working in Africa, my intellectual project so far has focused on 'studying-up' (Nader 1969) to examine how African elites negotiate the complex social and political relations of power that define their lives. Mbembe's theoretical impulses have stimulated my work on elites in Cameroon (see, for example, Orock 2014; 2015). Here, I am particularly interested in this early African postcolony from the vantage point of two archives: anthropological accounts by way of conventional ethnographic stories and literary accounts by way of African fiction of the period. Parsing these two archives opens up interesting possibilities for considering how the literary account enriches and even supplants the stories told by (especially colonial expatriate) anthropologists of that early postcolony.

In both its ethnographic imagination and anthropological complexity, I argue, African literary production (especially African fiction and drama) defined, and in some measure prefigured, a theory of power in the postcolony as we have come to know it since Mbembe's 'Provisional notes' essay and On the Postcolony, his subsequent, more definitive study on the theme. In the spirit of Mbembe's own methodologically innovative approach, I propose to show here how the political anthropology of Achebe's fiction is exemplary of a particular kind of literary description of the early postcolony.

In both Mbembe's 1992 essay and his 2001 book On the Postcolony, the African novel constitutes an important source for ethnographic descriptions and/or

\footnotetext{
${ }^{1}$ We encounter it, or versions of it, in the media and in scholarly commentary about the continent. Located on the surface, as well as deep in the crevices of racist tropes, it thrives in the now wellrehearsed language and imagery of barbarism, 'collapse' or 'darkness', tradition or 'backwardness'. These racist tropes, in one way or another, conjure Africa as an infantile place, and Africans as people 'lacking' and still in need of civilization - both place and people caught up in a timeless space of abjection (cf. Mbembe 2001; Mudimbe 1988).
} 
comparisons - informants of sorts - through which he addresses the questions of sovereign power, corruption, waste and consumption in the postcolony. Chief among these are the works of Congolese novelist Sony Lab'ou Tansi and that early figure of Nigerian literary production Amos Tutuola. In 'Provisional notes', for example, Mbembe draws on Lab'ou Tansi's descriptions of the 'tropicalities of His Excellency' as well as the roles of 'the strong, thick, delivering thighs' and 'the essential, bewitching arse' of girls in bringing about the 'digital orgasms' of leaders (Mbembe 1992: 6). Such works of early African fiction have helped to animate Mbembe's anthropological imagination, including in one of his latest books, Critique of Black Reason (2017).

Thus, imaginative literature from Africa has served as a fertile ground of inspiration for Mbembe's socio-cultural critique and political analysis of elites and postcolonial power in Africa. Here, I examine two novels by Chinua Achebe: No Longer at Ease (1960) and A Man of the People (1966). These two novels grapple with the complexities of elite power and corruption in a nascent postcolonial Nigeria in the 1960s. My analysis is situated along the general orientation of a sociology and anthropology of art and literature (Albrecht et al. 1970; Eagleton 1988) or more specifically what is now commonly viewed as a literary anthropology tout court (Nyamnjoh 2017a; Nic Craith and Fournier 2016; Rapport 2011; 2016; Davies and Fardon 1991).

This literary anthropology examines not only the ways in which literature is shaped by and embedded in its social context in terms of its cultural origins and uses (aesthetic, political or otherwise), but also the ways in which literature, sociology and anthropology share similar styles and modes of socio-cultural interpretation of the human condition. This emerging field of literary anthropology 'raises many exciting epistemological questions about literature as a resource for anthropologists' (Nic Craith and Fournier 2016: 7). I will therefore begin by discussing how literary production in Africa's 'new nations' responded to the changing socio-political and cultural orders of the postcolony in ways that are highly enriching of anthropological representations of the era. I will then go on to discuss how the fiction of Chinua Achebe's two novels, No Longer at Ease and A Man of the People, illustrates so well this literary engagement with the anthropological question of shifting dynamics of corruption, elite leadership and postcolonial power in the specific context of Nigeria.

\section{Fiction, ethnography and the anthropology of the postcolony}

Published by this journal in 1992, Mbembe's article was both seminal and provocative for thinking about postcolonial power and its genealogies in colonial regimes of discipline. The central argument of that essay is well known. Like Michel Foucault, Mbembe recognized the role of the body and the violence meted upon it in the economy of discipline and death. However, in a provocative manner, he drew our attention to the materiality of the body in the constitution of (post)colonial sovereignty. Sovereign power was marked by an 'obsession' with the body's orifices (mouth, vagina, anus) and the fluids and odours emanating from them, as well as its protuberances (the phallus, buttocks, breasts, stomach, and so on).

Focusing on the multiple investments in the body, Mbembe indicated some of the different modes by which these bodies are (ab)used, fed, made to dance, work, and so forth, so they may 'tire out' in the end. These postcolonial processes of disciplining bodies through pain and pleasure, he argued, generate multiple registers of 
complicity between authorities and people - so that, in the end, both become 'disempowered' (Mbembe 1992: 8-9). Essentially, Mbembe insisted, sovereign power is as much about bringing death as it is about the possibilities of life and its enjoyment. That is, the orifices and protuberances of the body make possible an 'orgiastic enjoyment of power' or jouissance tout court (Mbembe 2006). After all, he writes, 'the body in question is firstly a body that eats and drinks, and secondly a body that is open - in both ways', to take in and give out substances and vitalities (Mbembe 1992: 7; cf. Warnier 2007). Similarly, following Foucault, Judith Butler (1997: 34, 53) has also written that a focus on 'bodily subjection' through 'the immanent relation of pleasure and pain' is important to the contextualization of the 'psychic life of power'. For Mbembe, one way to undertake this contextualization is by emphasizing the multiple processes by which the banality of 'corruption' - (ab)uses - links both. As he puts it elsewhere, 'the mutual corruption' of bodies demands an account of both 'the psychic life' and the 'sensorial life of power' (see Mbembe 2006).

Mbembe's work does not dwell directly on the issue of corruption in relation to elite power in Africa, or at least not in the sense in which the term has been widely used - to refer to the specific issue of failed bureaucratic governance and its consequences in Africa - by sociologists, political scientists, anthropologists, and even historians. But his descriptions of the aesthetics of obscenity, through multiple cultural registers, emphasize the 'violent pursuit of wrongdoing to the point of shamelessness' and constitute the 'baroque character of the postcolony' (Mbembe 1992: 14). ${ }^{2}$ In this sense, I would like to suggest that Mbembe's essay 'Provisional notes on the postcolony' - and the book that followed much later - offered a theoretically challenging and stimulating perspective on the overall character of the state. In particular, his critique underlines the ways in which the social and cultural workings of the (post)colonial state facilitate a culture of corruption (cf. Gupta 1995; Olivier de Sardan 1999; Smith 2007). Hence, this critique continues to inspire those working from several disciplinary perspectives within the social sciences and humanities. Yet, the appeal of Mbembe's critique, even three decades later, also lies in its methodological orientation and commitment to an ethnographic imagination that privileges African cultural archives. Notably, he mobilizes the literary archive effectively to elucidate the dynamics of complicity and the ambiguities of domination, resistance and disempowerment in colonial and postcolonial orders.

Certainly, Mbembe was not the first historian or anthropologist of Africa to address the question of the state, elites and corruption. Others - including JeanFrançois Bayart, Jean-Pierre Olivier de Sardan, Stephen Ellis and Jean-Pierre Warnier - had begun addressing this and similar issues in their own work at about the same time or even earlier than Mbembe. However, as I discuss below, the critical analysis of literary sources constitutes one of the original aspects of Mbembe's approach. My focus here is both on Mbembe's valuable theoretical insights on

\footnotetext{
${ }^{2}$ Remarkably, and in contrast to the article, in the book that followed almost a decade later, On the Postcolony (2001), corruption is a prominent and explicit element in the characterization of colonial and postcolonial sovereignty: it appears in almost ten entries in the index. It features especially in Chapter 2, 'On private indirect government', which offers a historical sociology of the political economy of violence, extraction and extraversion in Africa. The first mention of corruption is as one of the strategies of domination adopted by colonial sovereignty, the commandment. Together with coercion, both were 'designed to alter the moral behavior of the colonised' (Mbembe 2001: 31).
} 
postcolonial jouissance and on his methodological commitment to the African literary imagination, especially the African novel, as an important cultural archive from which to creatively engage with African lifeworlds.

Literary production arising out of those early years became increasingly critical in this regard in several parts of the continent. These literary works defined and expressed the hopes, aspirations and postcolonial disaffections and disillusionment that Africanist social science has largely left unaddressed (for exceptions, see, for example, Adebanwi 2014; Piot 2010; Diamond 1989; Gugler 1988). Thus, African literature was trenchant in its critique of the new elite in Africa from the onset of the postcolonial experience. As Abiola Irele observes in an introduction to Femi Osofisan's The Oriki of a Grasshopper and Other Plays, African literature emerging during this period adopted a very 'critical observation' of the changed 'sociopolitical order and the conditions of a problematic modernity' (Irele 1995; see also Gugler 1988). As these new socio-political orders quickly became defined by personal rule and dictatorships under one-party state or military regimes (see Zolberg 1966), African literary works consistently engaged with and represented the changing social structures and cultural practices associated with the politics of the new nations and the African elites at their helm.

In poetry, such critiques include Wole Soyinka's A Dance of the Forests (1963), which was written specifically as a critique of celebrations of Nigeria's independence. In African novels such as Les Bouts de Bois de Dieu: Banty Mam Yall (1960), ${ }^{3}$ Ousmane Sembène offered a representation of the new African bourgeoisie in Senegal and Mali. Similarly, in The Beautyful Ones Are Not Yet Born (1988 [1968]), set in newly independent Ghana, Ayi Kwei Armah adopts a scatological style to describe the complex landscapes of depravity, complicity and moral corruption that unite both elites and the masses (cf. Ajakah 2018; Niemi 2017; Ogede 2000). In that novel, members of the political elite, like the lecherous Koomson, are represented through the imagery and metaphors of corruption, deformity, protuberances and odours that are the signs of postcolonial greed, decay and excrement: pot bellies, smelly latrines, consumption of high-end goods amidst widespread poverty and lack of necessities, and so on. This critique of postcolonial authority was also evinced in drama, for example in Ama Ata Aidoo's The Dilemma of a Ghost (1965). The huge contribution of this literary archive to social and cultural critique and the interpretation of postcolonial society in Africa led the political theorist Patrick Chabal (1992: 8) to conclude that African writers 'did more to reveal the reality of postcolonial Africa than most African scholars'.

Thus, in its fullness, this literary archive conveys the contradictions, anxieties and uncertainties experienced by Africans as their countries marched along the so-called path to sovereignty and 'modernity'. In short, in much more vivid, though fictional, ways, these literary works convey the contradictions and tensions of postcolonial modernity in these new African states (cf. Comaroff and Comaroff 1993; MigraineGeorge 2003). Most notable is the emphasis on generational struggles between established elites educated in colonial metropolises in the 1930s and 1940s and younger men and women, some of whom were still trained abroad but who were increasingly educated in the newly established universities in African countries. These tensions

\footnotetext{
${ }^{3}$ An English translation was published shortly after (Sembène 1962).
} 
and contradictions, so readily apparent in the two novels by Achebe that I discuss below through the theme of elites and corruption, are absent in the ethnographic representations of anthropologists working at that time. In this sense, Achebe's novels are a useful resource for our efforts to define and elaborate a political anthropology and critique of power in the early postcolony.

So, for the purposes of this article, I discuss how Achebe's works of fiction represent familiar tropes of corruption and postcolonial decadence in the postcolony. My goal is to take his fiction seriously in anthropological analysis. As noted above, anthropologists increasingly recognize the value of literature as a potential (re)source for anthropological knowledge, beyond conventional ethnographic approaches (see, for example, Langness and Frank 1978; Banks 1990; Laterza 2007; Narayan 1999; Nyamnjoh 2011; Tallman 2002). This appeal of literature (particularly the novel) among anthropologists arises from the recognition and prescription of experimental practices of textual representation in anthropology that enhance the anthropological representation of social realities (see Bohannan 1966; Clifford 1988; Marcus and Cushman 1982; Marcus and Fischer 1986). This anthropological quest to engage with literature is usually confronted with the challenge of ethnography as a 'field-based' mode of knowledge production.

Ethnography is widely accepted as the paradigmatic approach in anthropology that employs careful and detailed descriptions to address the discipline's central question: 'What does it mean to be human?' (Blasco and Wardle 2007: 1). Ethnography has thus been long acknowledged as that which defines the anthropological approach to the critique of human culture and social reality (see Clifford 1980; Marcus and Fischer 1986). Yet, understood principally as participant observation, there is also a weariness with the reduction of the anthropological project to ethnography (cf. Ingold 2014). In reality, ethnographic writing itself is not unlike other textual forms of fictional representation common to literature (Clifford 1980; 1986; 1988; Webster 1982). In the end, anthropology and literature both 'claim to capture life' (Fassin 2014: 41).

Literary production in general and novels in particular enrich the ethnographic imagination of anthropologists working in particular times and places (contexts). Indeed, 'the novel', Clara Reeves wrote (cited in Ross 1975: 29), is a picture of real life and manners, and of the times in which it was written. Specifically, in acknowledgement of anthropology's kinship with literary studies, some contemporary approaches in anthropology think of novels as 'ethnographic terrains' that alert the social science researcher to 'less visible' or neglected themes and aspects of a given phenomenon (Fine and Martial 2012: 156). Furthermore, 'social scientists and anthropologists "borrow" from the analogies and imagery often used in literary analysis'. The focus is on 'the social, political, and historical contexts' with which the literary texts engage and in which they are produced (De Angelis 2002: 1-2). For instance, in her famous essay 'Shakespeare in the bush', Laura Bohannan (1966) provides an illuminating demonstration of this affinity between anthropology and literature with her description and analysis of how the Tiv people in Nigeria interpreted and engaged with her narration of Shakespeare's Hamlet to them.

As with novels, the meanings embedded in ethnographic accounts are said to be 'allegorical' and 'uncontrollable' in the sense of how they are received by readers (Clifford 1986: 99, 119). Also, another important feature common to both the novel 
and anthropological representation is the compelling power of 'the story' as a narrative form: in both the novel and ethnography 'we perceive ourselves, our lives, as narrative, as story' (Brink 1998: 14). Thus, while it is true that fictionalized accounts in novels are copies that are never fully reality in the sense of the ethnographic present (Goody 1997), both forms seem to share a common concern with representing the lives people live, have lived, or could live. Indeed, this worry about the boundary between ethnography and the literary is not new: note, for example, the pedagogic efforts to cultivate some traditions of writing among African students at the prestigious William Ponty School in Senegal (see Warner 2016). Yet, part of the task of decolonizing anthropology today involves the ways in which we can move past the 'conventional' anthropological fixation with the idea that the only real and valid ethnographic informant is the 'individual (and living) subject' (Bubandt 2009: 296). There is some cognitive ambivalence involved in dealing with fiction and a putative truthful reality. Even so, the epistemological value of literature for the anthropologist can be broadly envisaged in at least three orientations: in relation to an archival search for 'sources'; in relation to the search for alternative modes and styles of writing; or, lastly, in relation to inquiries into the modes and practices of literary and cultural production (Wiles 2018). My own orientation here is inscribed in the first: the quest to fill what seems like a gap in anthropological representations of the early postcolony in Africa.

My effort to link Mbembe's anthropological critique of the postcolony to Achebe's literary representations of postcolonial politics builds on this recognition of the affinity between anthropology and literature. I use the two novels by Chinua Achebe as examples to examine the themes of elites, corruption and postcolonial decay in the early years of Nigeria's development. I analyse the relevance of Achebe's novels for understanding Nigeria as a country that has been plagued by narratives of corruption and the absence of a morally disciplined elite - two defining themes of its trajectory as a postcolonial state. Yet, given the remarkable absence of anthropological observations and analysis on these themes during that era, I show how Achebe's novels serve as an ethnographic informant that helps contextualize the cultural development of postcolonial jouissance among Nigeria's elite. In this sense, my analysis of Achebe's novelistic work also reveals his astuteness as a social and cultural critic as well as a political thinker of the postcolony.

\section{Chinua Achebe and Nigeria's postcolony}

Like many still do today, Mr Green attributes Obi Okonkwo's involvement in an act of bribery and the phenomenon of corruption itself in Africa to the racial constitution of Africans. To be more precise, he attributes them to the impact of Africa's harsh geography and climate on 'the mental and physical' abilities of Africans as a race. As he sees it, through colonialism the white man brought 'Western education' to the African, but this was clearly futile: 'what use' has it been to Obi Okonkwo, he asks (Achebe 1960: 30)? In Catherine Lynnette Innes's (1990: 43) excellent examination of Achebe's works, she remarks that Green and his fellow British members of the colonial social club see 'Obi and all Africans' as people of 'a race apart, whose psychology and mentality is permanently alien'.

In this sense, Mr Green, a colonial official, was also making an anthropologically problematic claim about Africans as racially different from Westerners, who would be 
morally superior and not so corrupt. As Chinua Achebe (1978: 2) writes, colonial racism is the foundational 'image of Africa' in that it is 'the desire - one might indeed say the need - in Western psychology to set Africa up as a foil to Europe, a place of negations at once remote and vaguely familiar in comparison with which Europe's own state of spiritual grace will be manifest'. Of course, as in many other respects, this colonial racism in relation to corruption persists to this day. In reality, it sidesteps the multiple layers of complicity, old and new, in the networks and flows of corruption within which Africans, Westerners and the rest of the global capitalist order operate in postcolonial enclaves (cf. Ferguson 2006).

I have been concerned with the issue of elites and postcolonial power at a particular historical moment: the early postcolony. In recent years, corruption has been a defining theme in studies of the trajectories and narratives of postcolonial power in Africa. Particularly striking is the corruption of African elites and their attachment to an orgiastic enjoyment of the material resources and privileges that their power confers upon them; these elements have featured prominently in recent histories and ethnographies of postcolonial power. Nigeria has been a very rich, if by no means exceptional, context from which these critiques of postcolonial elites and corruption have emerged. Since about the turn of the twenty-first century, a number of publications on Nigeria's economy and society, drawn mainly from the disciplines of anthropology, political science and history, have made this case more compellingly than I could do here.

Within anthropology, Daniel Jordan Smith's A Culture of Corruption: everyday deception and popular discontent in Nigeria (2007) received widespread attention at a time when Nigeria and Nigerians were increasingly known for and stereotyped by the various advance-fee fraud schemes and scams encapsulated by the '419' section of the Nigerian criminal code. The book triggered intense conversations around the complex moralities and practices of everyday corruption within which both elites and ordinary Nigerians are entangled. Only two years before Smith's publication, in an equally insightful and highly trenchant work, Andrew Apter had already drawn our attention to the role of oil as that dark substance that has served as the corrupting glue of Nigeria's nation since at least the 1970s. In The Pan-African Nation: oil and the spectacle of culture in Nigeria, Apter (2005) examines the multifaceted character of 'corruption' in Nigeria, including its despotic and nepotistic underpinnings and ramifications, as a result of petro-dollars. Combining anthropological methods with astute political reporting and analysis, Wale Adebanwi published Authority Stealing: anti-corruption war and democratic politics in post-military Nigeria in 2012. This is an important monograph on the fraught character, complex politics and contradictions in Nigeria's 'anti-corruption' campaigns following the country's return to civilian rule under the presidency of Olusegun Obasanjo.

Most recently, two historians, Steven Pierce and Stephen Ellis, have sought to bring the fractious politics of contemporary corruption discourse in Nigeria into more wide-ranging discussions of the foundations of the Nigerian polity, from its precolonial and colonial origins. In Moral Economies of Corruption: state formation and political culture in Nigeria, Pierce (2016) argues that, in contemporary Nigeria, corruption is a polysemic term that nonetheless denotes a singular understanding: the abuse of trust by ordinary citizens and political leaders in office, for personal gain. However, he insists on the importance of historicizing the 'political and cultural work' associated, 
over time, with how people come to recognize a wide range of activities and practices in Nigeria as part of this 'corruption'. From the starting point of northern Nigeria, Pierce offers an historical insight into the changing moralities associated with the meanings of corruption. Similarly, in the last book he would write, This Present Darkness: a history of Nigerian organized crime, Stephen Ellis (2016) remarks that the contemporary experience of corruption in Nigeria has old and complex genealogies that have only been made worse by the country's leadership: 'Nigeria had the misfortune to acquire a political elite and a political system that were shot through with practices of fraud and embezzlement, not to mention illicit violence' (ibid.: 4). Indeed, writing immediately after the civil war of 1966 that devastated the new Nigerian polity, Walter Schwarz - that irreverent and long-time commentator on Nigeria affairs remarked: 'That politicians were corrupt became less and less of a secret, until it reached even the necessarily-restrained pages of Lagos newspapers' (1968: 35). At their core, these histories and ethnographies of postcolonial power, including their focus on the elites and corruption, define the shifting horizons from postcolonial euphoria and hope, on the one hand, to multiple registers of decay, disenchantment and disillusionment.

Chinua Achebe is one of Africa's most distinguished literary figures. Like his other well-known contemporary, Wole Soyinka, Achebe is Nigerian. He was born on 16 November 1930, in the south-eastern Nigerian town of Ogidi, not too far from the buzzing and electrifying urban centre of Onitsha. After his graduation from University College in Ibadan in 1954, he first worked for the Nigerian Broadcasting Service (NBS) before eventually embarking on a full-time career in writing and university teaching, first at the University of Nigeria in Nsukka and then at several institutions in the USA.

Throughout his career, Achebe maintained a clear social commitment to the burning questions and issues of his time, including the divisive question of Ibo secession during the Nigerian-Biafran civil war of 1967, following the deadly coup of 1966 led by Major Chukwuma Kaduna Nzeogwu. While Achebe emphasized in his essay 'The role of the writer in a new nation' that '[a]fter all the novelist's duty is not to beat this morning's headline in topicality, it is to explore in depth the human condition', he nevertheless agreed that 'contemporary issues', including 'politics' or 'city life', are 'legitimate themes for the writer' (1964: 157, cited in Ogungbesan 1974: 43). From the outset, in his novels, short stories and critical writing, Achebe responded profoundly to the cultural and political crises of the postcolonial state in Nigeria. His most notable critiques of the Nigerian postcolony are set out in his essays The Trouble with Nigeria (Achebe 1983) and There Was a Country: a personal history of Biafra (Achebe 2012). Published shortly after his return to Nigeria in 1976, following a decade in the USA, The Trouble with Nigeria stated in its very opening salvo that, given ' $\mathrm{t}$ ] here is nothing basically wrong with the Nigerian character', the country's fundamental problem is 'simply and squarely a failure of leadership' (Achebe 1983:1). In his assessment, 'the seminal absence of intellectual rigour in the political thought of our founding fathers' was matched only by their 'tendency to pious materialistic wooliness', wherein we find a towering and highly admired figure such as Obafemi Awolowo affirming his faith in money and enrichment while Nnamdi Azikiwe pledged to 'utilize my earned income to secure my enjoyment of a high standard of living' (ibid.: 11). Instead of 'selfless leaders of their people', Achebe concluded that this plain 
devotion to enrichment and enjoyment could only lead Nigeria to 'produce aggressive millionaires' (ibid.: 11). Similarly, There Was a Country offers not only Achebe's recollections of the events leading up to and during the Nigerian-Biafran civil war but also his assessments of 'Nigeria's painful transitions', the role of corruption in state failure and the rise of terrorism. These are all ills that still plague the most populous country in Africa today. Thus, following Tejumola Olaniyan (2001: 22), Achebe's political novels elaborate an 'archaeology of the postcolonial African state' whose origins can be traced from the dislocations and ruptures of colonialism first described in Things Fall Apart (1958) and continued in the struggles described in Arrow of God (1964), which all culminate in the crises experienced in postcolonial decadence described in No Longer at Ease (1960) and A Man of the People (1966). The collective and cumulative insights from a careful reading illustrate how Achebe's major novelistic oeuvre on this theme is 'unusually prescient' in terms of how it 'foreshadows the crisis of legitimacy facing postcolonial African states today' (Olaniyan 2001: 22).

As Emmanuel Obiechina (1976: 126) argues, Achebe's novels are also defined by the use of scatology to 'prick the vast bubble of respectability blown up by the African elite', particularly in those early years after independence. The novels I discuss here share the same political sensibility: the representation of corruption and decadence as the defining features of the late colonial and early postcolonial political culture in Africa. I will therefore discuss these novels in terms of the broader sense of Mbembe's notion of jouissance. But more than that, the two novels underscore the complex social and cultural fabric within which elite jouissance and corruption thrive. The novels underline the kinds of social pressures, complicities and entanglements that produce elites such as Obi Okonkwo. This is a social matrix that has been described as the 'moral economy of corruption' in Africa (Olivier de Sardan 1999; cf. Smith 2007). In vivid and intricate descriptions, Achebe uses his literary imagination to provide an anthropologically informed response to Mr Green's British Council friend who asked why a young man like Obi would take a bribe and jeopardize his fledgling career as a young Nigerian civil servant.

With reference to No Longer at Ease, I unpack the cultural dynamics of mutuality and complicity that connect elites and their communities in postcolonial Africa. I then discuss the theme of decadence in A Man of the People in relation to the raw politics of sexual corruption. I conclude by returning to my initial discussion of the value of this African literary archive for anthropological discussions of the representation of elites in the African postcolony.

\section{No Longer at Ease: corruption and complicity}

No Longer at Ease (1960) is the second novel in a trilogy that also includes Achebe's first novel, Things Fall Apart (1958), and his third, Arrow of God (1964). All engage with the structural and deep psychological changes that result from the colonial encounter between actors from the Igbo communities and the exigencies of 'modernizing' European institutions in Nigeria. Achebe had used the first novel to criticize European misrepresentations of African people undergoing the colonial experience. No Longer was his attempt to depict African practices of postcolonial accommodation and adaptation to these social and institutional changes. The novel is mainly about the trials and tribulations of Obi Okonkwo, a young man from the Igbo-speaking 
community of south-eastern Nigeria who has recently graduated with a BA in Classics from a British university and has just returned to Nigeria, where he submits to the temptations of an increasingly corrupt and corrupting society.

Initially, Obi is a scathing critic of corruption and those who take bribes. He associates the vice mainly with a lack of education and a lack of awareness of its ills. Hence, he blames the older generations of less well-educated African civil servants. In his mind, the 'public service of Nigeria will remain corrupt' until this old guard is replaced with younger workers who have obtained that precious 'philosopher's stone', the university degree (Achebe 1960: 6, 92). Obi's education in Britain is made possible by the collective efforts of his village of Umuofia, whose Umuofia Progressive Union selects him as the first recipient of a scholarship in the form of a loan. The expectation of his kinsmen is that the loan will be repayable upon Obi's graduation, return and employment in a top government agency with a high salary and other perks.

This socially embedded and culturally inscribed (village) process by which Obi becomes an elite is the first and perhaps most vital depiction of the symbolism of corruption for the new African elite. No doubt the result of the moral failures of elite individuals, corruption is nevertheless a collective responsibility. In the collective imaginary of his kinsmen, Obi's success is a collective triumph: the entire community of villagers, especially those living in the same city as him (Lagos), can proudly point out that they too have produced an elite figure. ${ }^{4}$ His success is a shining example of collective agency. Just as much as a child is his or her community's responsibility, the community can take pride in his success (see Nyamnjoh 2002; 2004). Hence, members of his community proverbially describe Obi as 'an only palm kernel'. For this reason, he must be handled with care, lest they lose him to the jealousy and envy of other rival communities. This is especially the case because Obi arrives from England with a fiancée (Clara) from another community that they disapprove of (Achebe 1960: 6). This collective pride in Obi as the first, newly minted elite figure of the Umuofia people is expressed in superfluous phrases used during the welcoming ceremony organized in his honour by his kinsmen:

Welcome Address presented to Michael Obi Okonkwo, B.A. (Hons), London, by the officers and members of the Umuofia Progressive Union on the occasion of his return from the United Kingdom in his quest for the Golden Fleece. Sir, we the officers ... present with humility and gratitude this token of our appreciation of your unprecedented academic brilliance. (Achebe 1960: 31)

Given this reverence for Obi as their new elite figure, an 'illustrious son and guest of honour', they are disappointed when, in addition to addressing them in English, which 'was most unimpressive', Obi shows up at his own welcoming ceremony dressed in 'his shirt-sleeves because of the heat' when they had been expecting him to don the latest designer costume from London (Achebe 1960: 32).

The novel opens with the scene of Obi at his trial on corruption charges, specifically for taking a bribe in exchange for exerting his influence over the award of a

${ }^{4}$ Cf. Geschiere (1982) and Smith (2007) for careful analyses of this imagination of the new elite in the ethnographic contexts of Cameroon and Nigeria respectively. 
scholarship to the niece of the person who offered the bribe (Achebe 1960:1-2). Just as Obi's academic success and eventual employment with the Government Scholarship Board have been a source of collective pride, so too do his eventual conviction and sentence mean collective embarrassment, shame and dishonour for his kinsmen in Lagos. They convene a meeting at the residence of the president of the village improvement union to find ways to help Obi get out of trouble. Here, a fellow villager in the city complains that "we paid eight hundred pounds to train him in England ... instead of him being grateful he insults us because of a useless girl and now we are being called together again to find more money for him. What does he do with his big salary?' (ibid.: 5). The president of the union feels rather insulted by the small amount that has now tarnished Obi's reputation in the city of Lagos, saying, 'I am against people reaping where they have not sown. But we have a saying that if you want to eat a toad you should look for a fat and juicy one' (ibid.: 6). This implies that Obi should have sought or requested a larger bribe in return for the service provided.

Another fellow villager in the union suggests that Obi's misfortune arises from his "lack of experience, he should not have accepted the money himself. What others do is to tell you to go and hand it to their houseboy. Obi tried to do what everyone does without finding out how it was done' (Achebe 1960: 6). The comments of Obi's kinsmen betray a fascinating familiarity and complicity with the phenomenon of elite corruption, particularly with regard to giving and taking bribes. In fact, when Obi's friend Joseph proudly tells his colleagues about Obi's job as secretary at the Scholarship Board, one pertinently remarks: 'E go make plenty money there. Every student who wan go England go go seeam for house' (ibid.: 77). In other words, Nigerian public servants are clearly very corrupt - a reflection of popular expectation in Nigerian society more broadly (cf. Ogede 2001: 55).

There is an important lesson to take from such representations of the new African elite: that the 'making' of Obi into an elite figure in this fictional Igbo community exemplifies a communitarian mode of social production of elites. This is a mode that underlines the salient role of kinship in understanding corruption as a widely shared symbolic and material universe in postcolonial Africa (cf. Olivier de Sardan 1999; Blundo et al. 2006). Accordingly, Smith's $(2001 ; 2007)$ ethnography of everyday corruption in south-eastern Nigeria in the 1990s and 2000s supports Achebe's descriptions of popular understandings and expectations regarding elites. Put simply, there is a communitarian ethic regarding expectations of success and blurred perceptions of corruption. As one kinsman puts it at the meeting of the Umuofia Progressive Union in the novel:

We are not asking him to bring his salary to share among us. It is in the little things that he can help us. It is our fault if we do not approach him. Shall we kill a snake and carry it in our hand when we have a bag for putting long things in? (Achebe 1960: 80)

Obi is, in their view, 'a snake' they killed collectively and so they all expect to 'partake' in its eating (cf. Bayart 1993; Chabal 2009).

To follow Francis Nyamnjoh's (2017b; 2020) argument about 'incompleteness' as a global ontological reality, this entanglement of kinship in the social production of elites contextualizes expectations of reciprocity and their connections to corruption 
(cf. Bayart 1993; Chabal 2009; Daloz 2002; 2003; Olivier de Sardan 1999; Smith 2001; 2007). One's status as an elite is achieved through a constructive collaboration between one's kin, the community and one's self. Obi himself remarks that what his kin 'did not know was that, having labored in sweat and tears to enroll their kinsman among the shining elite, they had to keep him there' (Achebe 1960: 98). Obi feels that his kinsmen should go easy on collecting the loans they have given him as an educational grant.

Sherry Ortner $(1997 ; 2006)$ has argued that agency is a socio-cultural construction. In connection to this point, in Achebe's No Longer, the social drama of complicity between elite and ordinary people offers us a discerning insight into the workings of this cultural construction of postcolonial decadence among the elite. The web of moral obligations associated with kinship help push obi towards a corrupt transaction. Yet, ultimately, Obi succumbs to corruption out of his own propensity for the chrematistics that Mbembe attributes to contemporary African elites. As Mbembe (1992: 6; see also 2006: 159) writes, in Africa the social imaginary remains deeply embedded in struggles for material consumption that define a "marked taste for lecherous living'. Particularly among the elite, "[t]he "big men" among them live in huge palaces and enjoy luxuries that disregard the visible poverty among their people' (Falola 2003: 79). In Obi's case, this great desire for material consumption is connected to his reckless personal lifestyle. Although he is offered a four-month grace period by the union in which to settle into his new life without great financial stress, he foolishly turns this down out of scorn and pride. By paying the full amount of the loan outright, he hopes to 'undo' the bonds of kinship and the expectations of reciprocity that bind him to the union members. Moreover, he ignores the wise counsel about life in Lagos delivered to him during his welcome ceremony by the union's president: 'If you follow its sweetness, you will perish' (Achebe 1960: 82). He takes a new car on hire purchase but fails to make provision to pay for insurance. He also goes on to adopt a lifestyle that has him frequently out at dinners and in nightclubs with his fiancée, Clara. This is precisely what he has been warned against, although he does not think that he has 'been extravagant' (ibid.: 97).

\section{A Man of the People: the insecure virile postcolony?}

There is a striking similarity in the acerbic critique of the political culture of the early African postcolony in Achebe's A Man of the People and Armah's The Beautyful Ones. Ode Ogede (2000) claims that both novels share a common 'vision'. In A Man, Achebe perceptively rendered his sense of postcolonial unease with the new elite. This elite is held captive by its boundless taste for the good life and its enjoyment. This is particularly true of the relations that male elites enjoy with women. In Achebe's descriptions, the elite quest for postcolonial sexual enjoyment generates embarrassing displays of what Mbembe describes as pleonexia - 'the stupefaction experienced in pleasure'. This frenetic pursuit of sexual jouissance by the postcolonial elite is linked to older regimes of violence and extraction but ultimately it must be understood in part in relation to ' $\mathrm{t}] \mathrm{the}$ dialectics of power as enjoyment, enjoyment as possession, and possession as destruction' (Mbembe 2006: 160).

A Man is narrated solely through the voice of the main protagonist, Odili Samalu, a secondary school teacher. We first meet Odili at his school during a political campaign 
event for his former teacher, now turned member of parliament and Minister of Culture, Chief Dr Micah Nanga. The novel chronicles the total corruption of an elite with almost no moral fabric. Corruption is portrayed here predominantly through sexual affairs and through struggles among the leading men, although allusion is also made to their penchant for material accumulation. If the new elite in No Longer represented by the main protagonist, Obi, could attract sympathy from readers because his corruption seems to be the result of both social pressures and his own moral failings, in A Man the corruption is absolute and generalized. It is difficult to have empathy for Odili due to his lack of principles or values. The novel explores the theme of intergenerational struggle between the older and established elite, such as Nanga, and younger ones, such as Odili. In No Longer, Achebe gave only an indication of this struggle. Honourable Sam Okoli tells Obi about his younger Nigerian assistant secretary who was 'an idiot' whose 'head was swollen like a soldier ant because he went to Ibadan University', whereas he (the minister) takes pride in the fact that 'a white man who went to Oxford ... says sir' to him (Achebe 1960: 69). In A Man, this simmering intergenerational tension matures into full-blown conflict that is almost entirely articulated as a struggle over women and access to sexual gratification with women.

The first illustration of this preoccupation with sexual pleasure arises when Odili thinks about his plans to obtain a scholarship just so that he might have 'an opportunity to visit Europe' and the 'kick' it offers. He quips that he is not referring to the 'white girls - you can have those out here nowadays' (Achebe 1966: 19). Chief Nanga also hints at this theme of sexual gratification when he tries to entice Odili to make up his mind to visit him in the capital city, Bori, where he will offer him his 'guest-room' which is 'self-contained'. He says to Odili: 'You can live by yourself and do anything you like there, it's all yours' (ibid.: 20, emphasis in the original). Odili's sexual lust is further revealed when his friend Andrew visits him later in the evening after the minister's departure. As soon as Andrew walks in, he asks of him, 'Did you find out about that girl?', referring to the interest he expressed in Edna, Chief Nanga's soon-to-be second wife. He had seen her in the minister's company at the campaign event that features in the opening scene of the novel. His friend duly reproaches Odili: 'Why na so so girl, girl, girl, girl been full your mouth? Wetin? So person no fit talk serious talk with you' (ibid.: 23).

Odili dismissively introduces his own girlfriend, Elsie, to us in this way:

Well, Elsie! Where does one begin to write about her? ... Elsie was, and for that matter still is, the only girl I met and slept with the same day - in fact within an hour ... She was one of those girls who sends out cries in the heat of the thing. (Achebe 1966: 26-7)

This vulgar depiction of Elsie is soon followed by his account of his next-door neighbour, a medical student conveniently nicknamed 'Irre', short for 'irresponsible'. It is said that Irre manages to get the tough 'unbreakable' girl on campus and makes sure to emerge from his room sweating profusely while holding a used and sullied condom in his hand as evidence of his accomplishments (Achebe 1966: 28-9).

In turn, the Honourable Nanga's show of his sexual prowess is first represented when an American couple, Jean and John, visit him at home. Here, Jean is said to 'flirt 
eagerly with Micah'. This does not prevent Odili from having sexual relations with her later that evening after a party at her home at which Nanga cannot stay; he goes off for a sexual escapade of his own at a hotel in town (Achebe 1966: 53-9). In the end, Odili's sexual appetite collides with that of his friend and former teacher, the Honourable Minister Nanga, who, upon seeing Elsie, asks Odili: 'Tell me something, Odili. How serious are you about this girl, Elsie?' (ibid.: 28-9). Because Odili plays down his relationship with Elsie, calling her 'just a good-time girl', Nanga deems it reasonable that he too gets a taste of her, to the utter fury of Odili (ibid.: 73-83).

From this moment onwards all hell is let loose. Odili enters into politics and joins a friend, Max, to create a political party in a vain effort to exact revenge by trying to eject the minister from his parliamentary seat. Parallel to his effort on the political front, he launches an attack on the minister's 'romantic' life by dating the minister's soon-to-be second wife, Edna. In the end, their sexual proclivities get entangled with the political life of their Anata constituency. This effectively transforms the sexual politics of these two 'big men' into the deconstructive politics of the state to the extent that the country is thrown into chaos by a military coup.

If the postcolony is marked and marred by the pursuit of jouissance by the African elite in contemporary Africa, as Mbembe observes, the representations offered by the early African novel, as exemplified by Achebe's two works, amply indicate their presence right from its very start in the 1960s. Certainly fictional in their nature, the novels nevertheless conjure messy images of the elite culture of corruption in an African state that has continuously valued the pursuit of both forms of jouissance described by Mbembe. This critique of postcolonial political culture offers important insights into the social production and material conditions of elites. In comparison to these literary representations, how did anthropological studies engage with the political evolutions of the early postcolony? In the final section, I draw on a few examples to illustrate some of the limitations of anthropological representations of the period and the value of taking such literary representations more seriously for socio-cultural analysis today.

\section{Chinua Achebe and the anthropology of new states in Africa}

In his chapter in the volume Old Societies and New States: the quest for modernity in Asia and Africa that he edited, renowned anthropologist Clifford Geertz (1964) remarked of Nigeria that, at independence in 1960, '[t] he sort of form that leadership was to take, who was to provide it, and how, in the working of this Swiss-clock governmental mechanism, it was to actually be produced remained, however, entirely obscure'. Precisely for this reason, the question of postcolonial leadership in the new states was not insignificant. Yet, while this has become a dominant theme in recent historical and ethnographic studies, older ethnographic studies of the social and cultural anthropology of Africa do not offer any real sense of engagement with this question. Rather, owing to the colonial anthropology project, several works of the past focused mainly on trying to document the social organization and cultural practices of various African 'tribes'. It was feared that these were in danger of eventual 'extinction' because of the ongoing 'civilizing mission' that colonialism had initiated. For example, eminent British social anthropologists such as Lucy Mair (1962a) were still largely concerned with aspects of 'primitive government', even as she occasionally paid attention to current developments such as the elections in Nyasaland (Malawi) in 
1961 (Mair 1962b). This focus on the social structures of African societies under the changing conditions of the 'civilizing mission' seems to have been the basis for the establishment in 1925 of the British state-sponsored research institute the International Institute of African Languages and Culture (IIALC), later renamed the International African Institute (IAI). Summarizing the kind of research interests that mostly attracted the attention of Western ethnographers of the time, the African anthropologist Paul Nkwi has argued of the IAI's establishment of the Africa journal in 1928:

[It] inspired monographs on African politics (African Political Systems 1940, edited by Meyer Fortes, and Tribes Without Rulers 1958, edited by John Middleton, David Tait, and Laura Bohannan), cosmology and religion (African Worlds 1954, edited by Daryll Forde), witchcraft (Witchcraft and Sorcery in East Africa 1963, edited by John Middleton and E. H. Winter), and kinship (African Systems of Kinships and Marriage, 1956, edited by A. R. RadcliffeBrown and Daryll Forde) ... Beattie and Middleton edited Spirit Mediumship and Society in Africa (1969). (Nkwi 2006: 157-8)

Of course, there is no denying that anthropologists of that generation were interested in the study of African politics. However, this interest was not directed at practices that defined the everyday politics of that 'modernizing' time; rather, it was the 'primitive' or 'traditional' institutions and cultural practices of power and authority that concerned them. Corruption and authoritarian systems of personal rule were taking shape on the horizons of recently emerged postcolonial state formations in Africa. However, these seemed not to have been central to the ethnographic concerns of anthropologists working around that time.

In fact, although Mair has a chapter in Primitive Government entitled 'Primitive government and modern times', she was specifically interested in 'what has happened to the primitive political systems' of the various 'tribes' explored in the book (1962a: 256). In her ethnographic report of the Nyasaland elections, she does allude to the possible role that 'intimidation' and 'corrupt practices' might have played in the electioneering process (Mair 1962b: 28, 77). She points to 'the regulations dealing with corrupt practices' that were instituted for the 'special circumstances of Nyasaland', suggesting that these corrupt practices were related to concerns with spirituality or witchcraft: "“undue influence", threats to inflict ... by any supernatural or nonnatural means or pretended supernatural or non-natural means, any temporal or spiritual injury, damage, harm or loss' (ibid.: 28). These observations do not really reveal much about the everyday practices of corruption. Yet, leading political figures in Nyasaland at the time, particularly Dr Hastings Kamuzu Banda - leader of the Nyasaland African Congress Party from 1958 and leader of Malawi from 1964 to 1992 - were already linked to accusations of corruption (Englund 2002). In Mair's New Nations (1963), however, we find detailed ethnographic reflections on the social changes that these newly independent states were experiencing at the time. These reflections illustrate how tribesmen like the Tallensi and longstanding cultural practices such as marriage are coping with the demands of newly attained statehood as well as the changes in the 'balance of power' between the old elite (chiefs) and the new elite (state bureaucrats and politicians) through party politics. However, this book does not really address 'corruption' in relation to this new elite (ibid.). 
Similarly, Joan Vincent's African Elite: the 'big men' of a small town (1968) is very ethnographically detailed and astute in discussing the social strategies for upward social mobility in the small town of Gondo in Uganda. Like in Mair's work, however, we do not find references to corruption as a political practice by these elites or to the wider authoritarian political context of the Ugandan state that was evolving under Milton Obote at the time. Similar to Mair's and Vincent's studies, Arnold Epstein's very interesting account of Politics in an Urban African Community (1960 [1958]) does not engage with this question of the emerging African elite and the anxieties of postcolonial political leadership. The volume Social Change in Modern Africa, edited by Aidan Southall and Daryll Forde (1961), was equally focused on changes at the level of interpersonal and intercommunity relations while remaining mute on their implications for the broader political system and for emerging African elites.

Taken together, then, from the late colonial and early postcolonial moments, many anthropologists would have probably sensed the gradual but steadily evolving and changing guises of corruption and political decadence in African states, particularly among the emerging political elite. However, this is not apparent when we read their anthropological studies from the period. Yet, it is fair to say that Lucy Mair's and Joan Vincent's works were not the most dominant in terms of the prominent claims that anthropology as a discipline was making in relation to the understanding of culture, politics and society in Africa at the time. Although trained in anthropology, as women, they were not central figures in disciplinary debates. Mair trained at the LSE under Malinowski and, at the outbreak of World War Two, she joined the Royal Institute of International Affairs; the early part of her career was thus steered towards international relations and colonial administration, where she gained wide recognition for her work. Similarly, Joan Vincent's work, though eminent in its anthropological focus and meticulous in her analysis of social change in small communities, attracted little attention (probably less than it deserved).

Instead, in addition to the earlier volume on African political systems edited by Meyer Fortes and E. E. Evans-Pritchard (1940), the scholarly outputs that most shaped anthropological interest in African politics following the first wave of independence were the two volumes edited by Marc J. Swartz, Victor Turner and Arthur Tuden. The first, Political Anthropology (Swartz et al. 1966), was borne out of panels at the American Anthropological Association (AAA) meeting in 1964. The second, Local-level Politics (Swartz 1968), was based on a collection of papers presented at the WennerGren conference of 1966 . Both volumes (more than thirty contributions across the two) sought to take political anthropology beyond the focus on social structure and the village (as a local setting). The key analytical concepts of this approach were a focus on process, social change and local-level politics - although here the focus on local politics was understood to mean part of a wider and more complex social whole. Here, too, the extensive case method pioneered by the leading figures of British social anthropology, particularly those in the Manchester School such as Max Gluckman (see Werbner 2020), was seen as the dominant methodological approach to lead the anthropologist beyond the confines of local fieldwork. This processual approach also meant that 'the local' was now thought to be enmeshed in broader social and political relations and organizations.

Aside from the fact that this new movement in political anthropology was driven by Western scholars, it was also predominantly led by male scholars, who, while well 
aware of the impact of colonialism on colonized societies, failed to adequately problematize this question in terms of the relations of power in the new situations it created (Balandier 1952; Asad 1973; Mafeje 1976). Thus, these disciplinary developments in political anthropology did not sketch a context for postcolonial analyses in which the new nations, the new elite and the issue of corruption could emerge as salient themes. That is, this 'new' political anthropology failed to critically engage with the colonial origins of the new nations and the issues of postcolonial leadership and elite corruption so poignantly raised by Achebe's novels. And yet, as Peter Ekeh (1975) argued in his seminal essay, the fundamental questions of nation building and political leadership in postcolonial contexts are intricately bound to colonial dislocations of precolonial societies. In the end, the postcolonial order in new nations in Africa is fragmented into 'two realms': the primordial and civic, with their corresponding moral and amoral foundations and two publics. Ekeh's thesis of the 'two publics' illustrates the postcolonial dilemma of leadership for elites in the new nations that Achebe raises in No Longer at Ease: the new elite persons are torn between their responsibility towards the state and towards their 'own' people (village, ethnic or other groups). The reluctance of anthropologists in the early 1960 s to address the question of the elite and postcolonial decadence may have been related to their struggle to get out of the anthropological confinement in the local. But it also appears to have been driven by their fear of falling back on a racist colonial discourse of the moral inferiority of Africans, as Mr Green does in No Longer at Ease. After all, in the 1960s, anthropology did not enjoy a particularly stellar reputation among the elite of the new nations, even though some among them (including Jomo Kenyatta and Nnamdi Azikiwe) studied the discipline. Unhindered by such fears of attacks as a proponent of colonial racism, Ekeh and African writers in the literary circles could more easily raise issues that seemed too sensitive for Western anthropologists. For anthropologists today, taking this literary archive seriously, as Achille Mbembe has done in his own work, is an important step in enriching and decolonizing the anthropological archive in African studies.

Acknowledgements. This article developed initially from my teaching of a postgraduate course at the Department of Anthropology at the University of the Witwatersrand, titled 'African ethnography', from 2017 to 2020. I thank my students in the various cohorts of this class whose responses and engagements with the materials we have shared in the course have shaped my own reading and understanding profoundly. At the annual conference of the African Studies Association of the United Kingdom (ASAUK) in Birmingham in September 2018, I presented a version of this article at a panel convened by Wale Adebanwi titled 'Provisional Notes on the Postcolony: Twenty-five Years After'. I thank both Wale Adebanwi and the IAI, which sponsored the panel as well as my trip to the UK. I also thank Oben Timothy Mbuagbo at the University of Buea, who many years ago first drew my attention to the pedagogic value of African literary production for social and political analyses. Additional research for this article in the summer of 2020 was supported by an ad hoc grant from the Research Committee of the Faculty of Humanities at the University of the Witwatersrand, for which I am also thankful. Last, I am grateful to the anonymous reviewers of this essay for their helpful comments and suggestions.

Competing interests. The author declares none.

\section{References}

Achebe, C. (1958) Things Fall Apart. London: Heinemann.

Achebe, C. (1960) No Longer at Ease. London: Heinemann.

Achebe, C. (1964) Arrow of God. London: Heinemann. 
Achebe, C. (1966) A Man of the People. Oxford: Heinemann.

Achebe, C. (1978) 'An image of Africa', Research in African Literatures 9 (1): 1-15.

Achebe, C. (1983) The Trouble with Nigeria. London: Heinemann.

Achebe, C. (2012) There Was a Country: a personal history of Biafra. New York NY: Penguin.

Adebanwi, W. (2012) Authority Stealing: anti-corruption war and democratic politics in post-military Nigeria. Durham NC: Carolina Academic Press.

Adebanwi, W. (2014) 'The writer as social thinker', Journal of Contemporary African Studies 32 (4): 405-20. Aidoo, A. A. (1965) The Dilemma of a Ghost. London: Longman.

Ajakah, J. C. (2018) 'The corruption quagmire in Armah's The Beautyful Ones Are Not Yet Born', Vanguard Nigeria, 21 January <https://www.vanguardngr.com/2018/01/corruption-quagmire-armahs-beautifulones-not-yet-born/>, accessed 20 July 2021.

Albrecht, C., J. H. Barnett and M. Griff (eds) (1970) The Sociology of Art and Literature: a reader. London: Gerald Duckworth.

Apter, A. (2005) The Pan-African Nation: oil and the spectacle of culture in Nigeria. Chicago IL: University of Chicago Press.

Armah, A. K. (1988 [1968]) The Beautyful Ones Are Not Yet Born. Oxford: Heinemann.

Asad, T. (1973) 'Introduction' in T. Asad (ed.), Anthropology and the Colonial Encounter. London: Ithaca Press.

Ashcroft, B., G. Griffiths and H. Tiffin (1995) The Postcolonial Reader. London: Routledge.

Balandier, G. (1952) 'The facts of colonialism: a theoretical approach', Cross Currents 2 (4): 10-31.

Banks, D. J. (1990) 'Resurgent Islam and Malay rural culture: Malay novelists and the invention of culture', American Ethnologist 17 (3): 531-48.

Bayart, J.-F. (1993) The State in Africa: politics of the belly. London: Longman.

Blasco, P. G. and H. Wardle (2007) How to Read Ethnography. New York NY: Routledge.

Blundo, G., J.-P. Olivier de Sardan, N. Bako-Arifari and M. T. Alou (2006) Everyday Corruption and the State: citizens and public officials in Africa. London: Zed Books.

Bohannan, L. (1966) 'Shakespeare in the bush', Natural History 75: 28-33.

Brink, A. (1998) The Novel: language and narrative from Cervantes to Calvino. Cape Town: University of Cape Town Press.

Bubandt, N. (2009) 'Interview with an ancestor: spirits as informants and the politics of possession in north Maluku', Ethnography 10 (3): 291-316.

Butler, J. (1997) The Psychic Life of Power: theories in subjection. Stanford CA: Stanford University Press.

Chabal, P. (1992) Power in Africa: an essay in political interpretation. New York NY: St Martin's Press.

Chabal, P. (2009) Africa: the politics of suffering and smiling. London: Zed Books.

Clifford, J. (1980) 'Review of Orientalism', History and Theory 19 (2): 204-23.

Clifford, J. (1986) 'On ethnographic allegory' in J. Clifford and G. E. Marcus (eds), Writing Culture. Berkeley CA: University of California Press.

Clifford, J. (1988) The Predicament of Culture: twentieth-century ethnography, literature and art. Cambridge MA and London: Harvard University Press.

Comaroff, J. and J. L. Comaroff (1993) Modernity and its Malcontents: ritual and power in postcolonial Africa. Chicago IL: University of Chicago Press.

Daloz, J.-P. (2002) Élites et Représentations Politiques: la culture de l'échange inégal au Nigeria. Pessac: Presses Universitaires de Bordeaux.

Daloz, J.-P. (2003) “'Big men” in sub-Saharan Africa: how elites accumulate positions and resources', Comparative Sociology 2 (1): 271-85.

Davies, C. and R. Fardon (1991) 'African fictions in representations of West African and Afro-Cuban cultures', Bulletin of the John Rylands Library 73 (3): 125-46.

De Angelis, R. (ed.) (2002) Between Anthropology and Literature: interdisciplinary discourse. London and New York NY: Routledge.

Diamond, L. (1989) 'Fiction as political thought', African Affairs 88 (352): 435-45.

Eagleton, T. (1988). 'Two approaches in the sociology of literature', Critical Inquiry 14 (3): 469-76.

Ekeh, P. (1975) 'Colonialism and the two publics in Africa: a theoretical statement', Comparative Studies in Society and History 17 (1): 91-112.

Ellis, S. (2016) This Present Darkness: a history of Nigerian organized crime. London: Hurst and Company.

Englund, H. (2002) A Democracy of Chameleons: politics and culture in the new Malawi. Uppsala: Nordiska Afrikainstitutet. 
Epstein, A. (1960 [1958]) Politics in an Urban African Community. Manchester: Manchester University Press. Falola, T. (2003) The Power of African Cultures. Rochester NY: University of Rochester Press.

Fassin, D. (2014) 'True life, real lives: revisiting the boundaries between ethnography and fiction', American Ethnologist 41 (1): 40-55.

Ferguson, J. (2006) Global Shadows: Africa in the neoliberal world order. Durham NC: Duke University Press. Fine, A. and A. Martial (2012) 'Anthropologie et roman: à propos des pères divorcés', Ethnologie Française 42 (1): 155-64.

Fortes, M. and E. E. Evans-Pritchard (eds) (1940) African Political Systems. Oxford: Oxford University Press.

Geertz, C. (1964) 'The integrative revolution: primordial sentiments and civil politics in the new states' in C. Geertz (ed.), Old Societies and New States: the quest for modernity in Asia and Africa. New York NY: The Free Press.

Geschiere, P. (1982) Village Communities and the State: changing relations among the Maka of southeastern Cameroon since the colonial conquest. London: Kegan Paul.

Goody, J. (1997) Representations and Contradictions: ambivalence towards images, theatre, fiction, relics and sexuality. Oxford: Oxford University Press.

Gugler, J. (1988) 'African literary comment on dictators: Wole Soyinka's plays and Nuruddin Farah's novels', Journal of Modern African Studies 26 (1): 171-7.

Gupta, A. (1995) 'Blurred boundaries: the discourse of corruption, the culture of politics, and the imagined state', American Ethnologist 22 (2): 375-402.

Ingold, T. (2014) 'That's enough about ethnography!', HAU: Journal of Ethnographic Theory 4 (1): 383-95. Innes, L. (1990) Chinua Achebe. Cambridge: Cambridge University Press.

Irele, A. (1995) 'Introduction' in F. Osofisan (ed.), The Oriki of a Grasshopper and Other Plays. Washington DC: Howard University Press.

Langness, L. L. and G. Frank (1978) 'Fact, fiction and the ethnographic novel', Anthropology and Humanism Quarterly 3 (1-2): 18-22.

Laterza, V. (2007) 'The ethnographic novel: another literary skeleton in the anthropological closet?', Suomen Antropologi: Journal of the Finnish Anthropological Society 32 (2): 124-34.

Mafeje, A. M. (1976) 'The problem of anthropology in historical perspective: an inquiry into the growth of the social sciences', Canadian Journal of African Studies 10 (2): 307-33.

Mair, L. (1962a) Primitive Government. London and Harmondsworth: Penguin Books.

Mair, L. (1962b) The Nyasaland Elections of 1961. London: University of London and Athlone Press.

Mair, L. (1963) New Nations. Chicago IL: University of Chicago Press.

Marcus, G. and D. Cushman (1982) 'Ethnographies as texts', Annual Review of Anthropology 11: 25-69.

Marcus, G. E. and M. F. Fischer (1986) Anthropology as Cultural Critique: an experimental moment in the human sciences. Chicago IL: University of Chicago Press.

Mbembe, A. (1992) 'Provisional notes on the postcolony', Africa 62 (1): 3-37.

Mbembe, A. (2001) On the Postcolony. Berkeley CA: University of California Press.

Mbembe, A. (2006) 'On the Postcolony: a brief response to critics', African Identities 4 (2): 143-78.

Mbembe, A. (2017) Critique of Black Reason. Durham NC: Duke University Press.

Migraine-George, T. (2003) 'Ama Ata Aidoo's orphan ghosts: African literature and aesthetic postmodernity', Research in African Literatures 34 (4): 85-95.

Mudimbe, V. Y. (1988) The Invention of Africa: gnosis, philosophy, and the order of knowledge. Bloomington and Indianapolis IN: Indiana University Press.

Nader, L. (1969) 'Up the anthropologist: perspectives gained from studying up' in D. Hymes (ed.), Reinventing Anthropology. New York NY: Vintage Books.

Narayan, K. (1999) 'Ethnography and fiction: where is the border?', Anthropology and Humanism 24 (2): 134-47.

Nic Craith, M. and L. S. Fournier (2016) 'Literary anthropology: the sub-disciplinary context', Anthropological Journal of European Cultures 25 (2): 1-8.

Niemi, M. J. (2017) 'Challenging moral corruption in the postcolony: Ayi Kwei Armah's The Beautyful Ones Are Not Yet Born and Hannah Arendt's notion of individual responsibility', Postcolonial Studies 20 (2): 217-36.

Nkwi, P. N. (2006) 'Anthropology in a postcolonial Africa: the survival debate' in G. Lins Ribeiro and A. Escobar (eds), World Anthropologies: disciplinary transformation within systems of power. Oxford and New York NY: Berg Publications. 
Nyamnjoh, F. B. (2002) 'A child is one person's only in the womb: domestication, agency and subjectivity in the Cameroonian Grassfields' in R. Werbner (ed.), Postcolonial Subjectivities in Africa. London: Zed Books.

Nyamnjoh, F. B. (2004) 'Reconciling "the rhetorics of rights" with competing notions of personhood and agency in Botswana' in H. Englund and F. B. Nyamnjoh (eds), Rights and the Politics of Recognition in Africa. London: Zed Books.

Nyamnjoh, F. B. (2011) 'Cameroonian bushfalling: negotiation of identity and belonging in fiction and ethnography', American Ethnologist 38 (4): 701-13.

Nyamnjoh, F. B. (2017a) Drinking from the Cosmic Gourd: how Amos Tutuola can change our minds. Bamenda: Langaa.

Nyamnjoh F. B. (2017b) 'Incompleteness: frontier Africa and the currency of conviviality', Journal of Asian and African Studies 52 (3): 253-70.

Nyamnjoh F. B. (2020) 'A post-Covid-19 fantasy on incompleteness and conviviality' in C. Besteman, H. Cabot and B. Kalir (eds), 'Post-Covid fantasies', American Ethnologist website, 27 July <https:// americanethnologist.org/features/pandemic-diaries/post-covid-fantasies/a-post-covid-19-fantasyon-incompleteness-and-conviviality>.

Obiechina, E. (1976) 'Post-independence disillusionment in three African novels' in B. Lindfors and U. Schild (eds), Neo-African Literature and Culture: essays in memory of Janheinz Janz. Wiesbaden: B. Heymann.

Ogede, O. (2000) Ayi Kwei Armah, Radical Iconoclast: pitting imaginary worlds against the actual. Athens OH: Ohio University Press.

Ogede, O. (2001) Achebe and the Politics of Representation. Trenton NJ: Africa World Press.

Ogungbesan, K. (1974) 'Politics and the African writer', African Studies Review 17 (1): 43-53.

Olaniyan, T. (2001) 'Chinua Achebe and an archaeology of the postcolonial African state', Research in African Literatures 32 (3): 22-9.

Olivier de Sardan, J.-P. (1999) 'A moral economy of corruption in Africa?', Journal of Modern African Studies 37 (1): 25-52.

Orock, R. T. E. (2014) 'Elites, culture and power: the moral politics of "development" in Cameroon', Anthropological Quarterly 88 (2): 533-68.

Orock, R. T. E. (2015) 'Anglophone elites and the politics of hosting Cameroon's head of state', Africa 84 (2): $226-45$.

Ortner, S. (1997) 'Thick resistance: death and the cultural construction of agency in Himalayan mountaineering', Representations 59: 135-62.

Ortner, S. (2006) Anthropology and Social Theory: culture, power, and the acting subject. Durham NC: Duke University Press.

Pierce, S. (2016) Moral Economies of Corruption: state formation and political culture in Nigeria. Durham NC: Duke University Press.

Piot, C. (2010) Nostalgia for the Future: West Africa after the Cold War. Chicago IL: University of Chicago Press. Rapport, N. J. (2011) 'Literary anthropology' in J. Jackson (ed.), Oxford Bibliographies Online: anthropology. Oxford: Oxford University Press.

Rapport, N. J. (2016) 'Fiction and anthropological understanding: a cosmopolitan vision' in H. Wulff (ed.), The Anthropologist as Writer: genres and contexts in the twenty-first century. Oxford: Berghahn Books.

Ross, M. L. (1975) 'Cooper's The Pioneers and the ethnographic impulse', American Studies 16 (2): 29-39. Schwarz, W. (1968) Nigeria. London: Pall Mall Press.

Sembène, O. (1960) Les Bouts de Bois de Dieu: Banty Mam Yall. Paris: Le Livre Contemporain. Sembène, O. (1962) God's Bits of Wood. London: Doubleday.

Smith, D. J. (2001) 'Kinship and corruption in contemporary Nigeria', Ethnos 66 (3): 344-64.

Smith, D. J. (2007) A Culture of Corruption: everyday deception and popular discontent in Nigeria. Princeton NJ: Princeton University Press.

Southall, A. and D. Forde (eds) (1961) Social Change in Modern Africa. Oxford: Oxford University Press. Soyinka, W. (1963) A Dance of the Forests. London: Oxford University Press.

Swartz, M. J. (1968) Local-level Politics: social and cultural perspectives. Chicago IL: Aldine.

Swartz, M. J., V. W. Turner and A. Tuden (1966) Political Anthropology. Chicago IL: Aldine.

Tallman, J. (2002) 'The ethnographic novel: finding the insider's voice' in R. De Angelis (ed.), Between Anthropology and Literature: interdisciplinary discourse. London and New York NY: Routledge.

Vincent, J. (1968) African Elite: the 'big men' of a small town. New York NY: Columbia University Press. 
Warner, T. (2016) 'Para-literary ethnography and colonial self-writing: the student notebooks of the William Ponty School', Research in African Literatures 47 (1): 1-20.

Warnier, J.-P. (2007) The Pot-King: the body and technologies of power. Leiden and Boston MA: Brill.

Webster, S. (1982) 'Dialogue and fiction in ethnography', Dialectical Anthropology 7 (2): 91-114.

Werbner, R. (2020) Anthropology after Gluckman: the Manchester School, colonial and postcolonial transformations. Manchester: Manchester University Press.

Wiles, E. (2018) 'Three branches of literary anthropology: sources, styles, subject matter', Ethnography 21 (2): 280-95.

Zolberg, A. (1966) Creating Political Order: the party-states of West Africa. Chicago IL: University of Chicago Press.

Rogers Orock is a senior lecturer in the Anthropology Department, University of the Witwatersrand. He is also a lecturer in the Department of Sociology and Anthropology at the University of Buea, Cameroon.

Cite this article: Orock, R. (2022). 'Chinua Achebe's postcolony: a literary anthropology of postcolonial decadence'. Africa 92, 71-92. https://doi.org/10.1017/S0001972021000838 